\title{
Growth of Impatiens, Petunia, Salvia, and Tomato Seedlings under Blue, Green, and Red Light-emitting Diodes
}

\author{
Heidi Marie Wollaeger ${ }^{1}$ and Erik S. Runkle ${ }^{2,3}$ \\ Department of Horticulture, Michigan State University, 1066 Bogue Street, \\ East Lansing, MI 48824
}

Additional index words. bedding plants, controlled environments, LEDs, light quality, transplants

\begin{abstract}
Plant growth and architecture are regulated in part by light quality. We performed experiments to better understand how young plants acclimate to blue (B), green (G), and red (R) light and how those responses can be used to produce plants with desirable morphological characteristics. We grew seedlings of impatiens (Impatiens walleriana), salvia (Salvia splendens), petunia (Petunia $\times$ hybrida), and tomato (Solanum lycopersicum) under six sole-source light-emitting diode (LED) treatments or one coolwhite fluorescent treatment that each delivered a photosynthetic photon flux (PPF) of 160 $\mu \mathrm{mol} \cdot \mathrm{m}^{-2} \cdot \mathrm{s}^{-1}$ for $18 \mathrm{~h} \cdot \mathrm{d}^{-1}$. Leaf number was similar among treatments, but plants grown under $25 \%$ or greater $B$ light were $41 \%$ to $57 \%$ shorter than those under only $R$ light. Plants under $R$ light had $47 \%$ to $130 \%$ greater leaf area and $48 \%$ to $112 \%$ greater fresh shoot weight than plants grown under treatments with $25 \%$ or greater $B$. Plants grown under only $R$ had a fresh shoot weight similar to that of those grown under fluorescent light for all species except tomato. In impatiens, flower bud number at harvest generally increased with B light, whereas in tomato, the number of leaflets with intumescences decreased with B light. This research discusses how light quality can be manipulated for desired growth characteristics of young plants, which is important in the production of specialty crops such as ornamentals, herbs, and microgreens.
\end{abstract}

Light-emitting diodes are well suited for commercial plant production because of their high energy efficiency and spectral specificity (Mitchell et al., 2012). When operated at favorable temperatures, well-constructed LEDs have an operating lifetime of 50,000 h or more, which is at least two times longer than conventional high-pressure sodium or fluorescent lamps (Bourget, 2008; Morrow, 2008). LEDs also have potential to be used as intercanopy lighting, to increase nutrient concentration in edible crops and to decrease pesticide and plant growth regulator applications (Cosgrove, 1981; Doukas and Payne, 2007; Hemming, 2011; Kumar and Poehling, 2006; Li and Kubota, 2009; Rapisarda et al., 2006; van Ieperen and Trouwborst, 2008; Watanabe, 2011; Weinig

\footnotetext{
Received for publication 2 Mar. 2014. Accepted for publication 22 Apr. 2014.

We gratefully acknowledge support from Osram Opto Semiconductors, the USDA-ARS Floriculture and Nursery Research Initiative, and Michigan State University's AgBioResearch. We thank Bert Cregg for statistical advice, Rajendra Swamy for development of the LED modules, C. Raker \& Sons for donation of plant material, and Randy Beaudry and Mike Olrich for technical assistance. ${ }^{1}$ Former graduate research assistant and currently commercial horticulture educator. Current address: Michigan State University Extension, 3299 Gull Road, P.O. Box 42, Nazareth, MI 49074.

${ }^{2}$ Associate Professor and Floriculture Extension Specialist.

${ }^{3}$ To whom reprint requests should be addressed. e-mail runkleer@msu.edu.
}

et al., 2004). Using LEDs for sole-source photosynthetic lighting is of commercial interest because high-density shelving systems could allow multiple-tiered growing, which can increase land use efficiency (Watanabe, 2011). In addition, the light spectrum can be customized for specific growth responses such as to inhibit or promote extension growth or deliver the most photosynthetically efficient light to increase biomass (van Ieperen, 2012). However, although LEDs enable the light spectrum to be tailored for desirable plant responses, few studies have been published on light manipulation on nonagronomic crops grown in highly controlled environments.

Sole-source lighting with B (400 to $500 \mathrm{~nm}$ ) or $\mathrm{R}$ (600 to $700 \mathrm{~nm})$ LEDs or fluorescent lamps has been studied primarily on agronomic crops (Massa et al., 2008). For example, wheat (Triticum aestivum) grown under a $P P F$ of 350 $\mu \mathrm{mol} \cdot \mathrm{m}^{-2} \cdot \mathrm{s}^{-1}$ from R LEDs (peak $=660 \mathrm{~nm}$ ) had $\approx 50 \%$ less dry weight than under $\mathrm{B}$ or white fluorescent lamps, and the instantaneous photosynthetic rate was $45 \%$ less than that of plants under white light (Goins et al., 1997). In contrast, when four cultivars of spinach (Spinacea oleracea) received a $P P F$ of 300 $\mu \mathrm{mol} \cdot \mathrm{m}^{-2} \cdot \mathrm{s}^{-1}$, those grown under $\mathrm{R}$ or white fluorescent light had $10 \%$ to $80 \%$ more biomass than plants grown under only B fluorescent light (Li et al., 2011). Spinach and several other species had thinner leaves with less chlorophyll and thinner, longer stems when irradiated with only R light, whereas plants grown under only $\mathrm{B}$ light had reduced biomass accumulation (Eskins, 1992; Fukuda et al., 1993, 2008; Li et al., 2011; Saebo et al., 1995). For example, Arabidopsis thaliana grown at a $P P F$ of $50 \mu \mathrm{mol} \cdot \mathrm{m}^{-2} \cdot \mathrm{s}^{-1}$ had less biomass under $\mathrm{B}$ fluorescent light and up to one-third shorter petioles compared with plants grown under $\mathrm{R}$ fluorescent light (Eskins, 1992). In the ornamental geranium (Pelargonium zonale), leaves were $\approx 16 \%$ thicker, particularly the palisade layers, when irradiated with $100 \mu \mathrm{mol} \cdot \mathrm{m}^{-2} \cdot \mathrm{s}^{-1}$ of B LED (peak $=460 \mathrm{~nm})$ light compared with those of plants irradiated with the same intensity of $\mathrm{R}$ (peak $=660 \mathrm{~nm}$ ) LED light (Fukuda et al., 2008).

Plants grown under a mixture of wavelengths could possess more desirable, marketable traits (e.g., more compact seedlings for transplanting or larger leaves for harvesting) than those grown under a single light waveband. Multiple waveband research with LEDs has focused on R and B light, and specific R:B responses have varied among studies (Goins et al., 1997; Kato et al., 2011; Yang et al., 2011). An R (peak $=660 \mathrm{~nm})$ to B $($ peak $=450 \mathrm{~nm})$ ratio of $8: 1$ produced sweetpotato (Ipomoea batatas) plants with the greatest root-to-shoot ratio, whereas plants grown under the highest ratio of $\mathrm{R}$ light (10:1) had the least (Yang et al., 2011). Providing $\mathrm{B}$ light in an R-dominant environment can also increase seed yield, increase chlorophyll content, and promote flowering in some crops (Goins et al., 1997; Imaizumi et al., 2003; Li et al., 2011; Ohashi-Kaneko et al., 2006; Saebo et al., 1995; Tennessen et al., 1994). For example, wheat plants grown under R LEDs (peak $=660 \mathrm{~nm}$ ) had approximately half of the number of tillers as plants grown under $90 \% \mathrm{R}$ LED light and 10\% B fluorescent light or white fluorescent light (Goins et al., 1997).

Plant growth under G (500 to $600 \mathrm{~nm}$ ) light alone can be poor: the net photosynthetic rate of cherry tomato (Lycopersicon esculentum var. cerasiforme) was approximately one-third as much when plants were grown under only $\mathrm{G}$ light (peak $=520 \mathrm{~nm} ; P P F$ of 320 $\mu \mathrm{mol} \cdot \mathrm{m}^{-2} \cdot \mathrm{s}^{-1}$ ) than under only $\mathrm{B}$ (peak = $450 \mathrm{~nm})$, only R (peak $=650 \mathrm{~nm})$, or B $+\mathrm{R}$ light (Liu et al., 2011b). However, the addition of $G$ light to $R$ and $B$ light can increase biomass accumulation in some crops. For example, lettuce (Lactuca sativa) was grown at $150 \mu \mathrm{mol} \cdot \mathrm{m}^{-2} \cdot \mathrm{s}^{-1}$ under $\mathrm{R}$ and $\mathrm{B}$ LED light with and without $G$ fluorescent lamps (Kim et al., 2004). Lettuce had lower rates of photosynthesis when the percentage of $\mathrm{G}$ light exceeded $50 \%$, but lettuce had $89 \%$ more biomass when the light spectrum included up to $24 \% \mathrm{G}$ light. Similarly, when lady slipper orchid was grown in tissue culture, plants under R, G, and B LEDs (ratio of $8: 1: 1$; peak $=660,525$, and $450 \mathrm{~nm}$, respectively) had $66 \%$ to $84 \%$ greater shoot dry weight than plants irradiated with only $\mathrm{B}, \mathrm{R}$, or a combination of $\mathrm{R}$ and $\mathrm{B}(9: 1)$ at the same $P P F$ (Lee et al., 2011). Therefore, in at least some crops, including wavelengths other than $\mathrm{B}$ and $\mathrm{R}$, can elicit a desired growth response.

We grew seedlings of four common annual crops under ratios of $\mathrm{B}, \mathrm{G}$, and $\mathrm{R}$ light to 


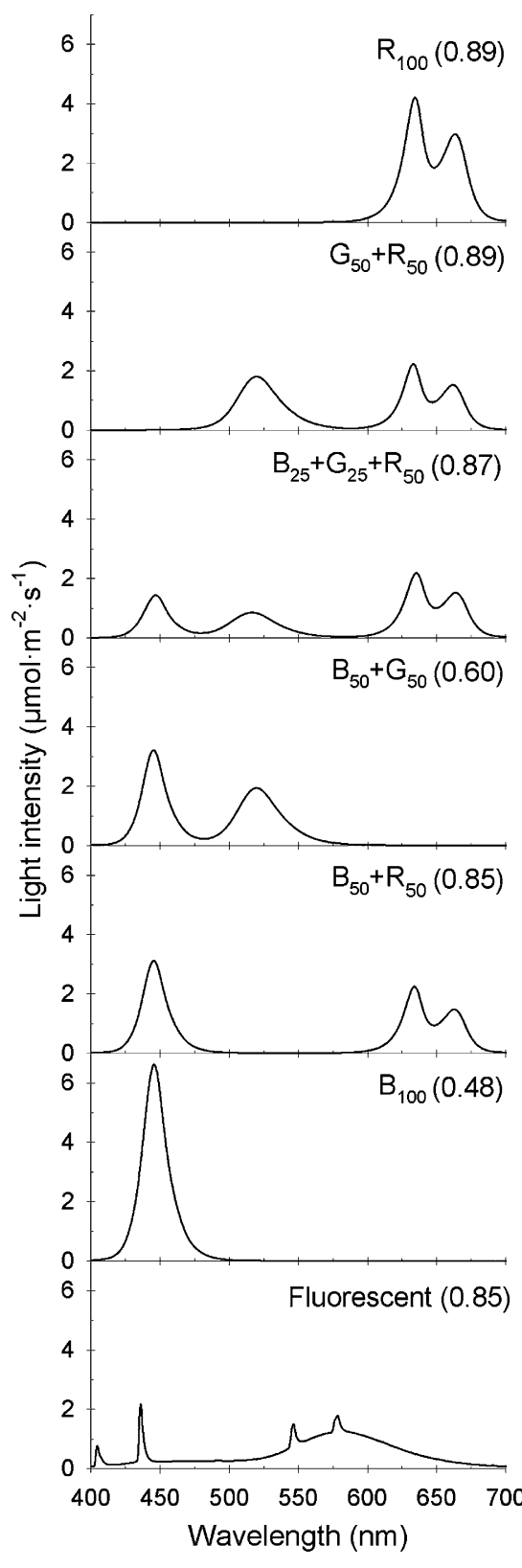

Fig. 1. The spectral distribution of six lightquality treatments delivered by blue (B), green $(\mathrm{G})$, and two types of red (R) lightemitting diodes (LEDs) and one treatment delivered by cool-white fluorescent lamps, each delivering a photosynthetic photon flux $(P P F)$ of $160 \mu \mathrm{mol} \cdot \mathrm{m}^{-2} \cdot \mathrm{s}^{-1}$. The subscript values after each LED type represent its percentage of the total $P P F$, and values in parentheses are the estimated phytochrome photoequilibrium (Sager et al., 1988).

better understand how the light spectrum regulated plant growth attributes such as leaf size and shoot biomass. Specialty-crop species were chosen for this study based on economic value and to include variation in plant family, plant habit, and shade adaptation. Our objective was to quantify how seedlings grew and acclimated to light quality treatments to help facilitate the production of young specialty crops with desirable morphological characteristics.

Table 1. Actual air and canopy temperatures $\left({ }^{\circ} \mathrm{C}\right)$ as measured by thermocouples and infrared sensors for the six light-emitting diode (LED) lighting treatments $(\mathrm{B}=$ blue; $\mathrm{G}=$ green; $\mathrm{R}=$ red) and one fluorescent lighting treatment. ${ }^{\mathrm{z}}$

\begin{tabular}{lcccc}
\hline & \multicolumn{2}{c}{ Replication 1 } & \multicolumn{2}{c}{ Replication 2 } \\
\cline { 2 - 3 } Light quality treatment & Air & Canopy & Air & Canopy \\
\hline $\mathrm{R}_{100}$ & 20.6 & 20.7 & 21.6 & 20.6 \\
$\mathrm{G}_{50}+\mathrm{R}_{50}$ & 20.9 & 21.1 & 21.6 & 20.9 \\
$\mathrm{~B}_{25}+\mathrm{G}_{25}+\mathrm{R}_{50}$ & 20.9 & 20.6 & 21.2 & 20.6 \\
$\mathrm{~B}_{50}+\mathrm{R}_{50}$ & 20.9 & 20.9 & 20.5 & 20.8 \\
$\mathrm{~B}_{50}+\mathrm{G}_{50}$ & 21.0 & 20.8 & 21.3 & 21.3 \\
$\mathrm{~B}_{100}$ & 21.4 & 20.8 & 20.9 & 20.6 \\
Fluorescent & 22.4 & 21.7 & 22.2 & 22.0 \\
\hline
\end{tabular}

${ }^{\mathrm{z}}$ Data were recorded every $10 \mathrm{~s}$ and a data logger recorded means every $10 \mathrm{~min}$ throughout the 36-d durations of the experimental replications. The subscript values after each LED type (where $\mathrm{R}$ was delivered equally by two different LEDs) represent its percentage of the total photosynthetic photon flux. All temperatures had a standard error $\pm 0.1^{\circ} \mathrm{C}$.

\section{Materials and Methods}

Plant materials. Seeds of tomato (Solanum lycopersicum 'Early Girl'), salvia (Salvia splendens 'Vista Red'), impatiens (Impatiens walleriana 'SuperElfin XP Red'), and petunia (Petunia $\times$ hybrida 'Wave Pink') were sown in 128 -cell $(2.7 \times 2.7 \mathrm{~cm} ; 12.0-\mathrm{mL}$ volume $)$ plug trays at a commercial greenhouse (C. Raker and Sons, Inc., Litchfield, MI). On arrival at Michigan State University, East Lansing, MI, a seedling tray of each species was then cut into sections, each with 20 or more seedlings, thinned to one plant per cell, and immediately placed in the lighting treatments.

Light treatments and environment. Six white rigid plastic LED light modules, custom-designed and constructed for experimentation, had four sides and were $80 \mathrm{~cm}$ deep, $27 \mathrm{~cm}$ wide, and $52 \mathrm{~cm}$ tall, as described by Wollaeger and Runkle (2013). The top of each module contained $\mathrm{B}$ (peak $=446 \mathrm{~nm}), \mathrm{G}($ peak $=$ $516 \mathrm{~nm}$ ), and two R LED types (peaks $=634$ and $664 \mathrm{~nm}$ ) that were facing downward inside the module. Eighty LEDs of each type were mounted on fan-cooled driver boards that were open to the environment to allow for adequate cooling. The light output of each color of LED could be adjusted manually by a dimmer switch. The LED modules were placed on open, metal mesh benches inside a refrigerated walk-in growth chamber.

Six light-quality treatments that delivered a $P P F$ of $160 \mu \mathrm{mol} \cdot \mathrm{m}^{-2} \cdot \mathrm{s}^{-1}$ emitted the following percentages: $\mathrm{B}_{100}(100 \%$ light from $\mathrm{B}$ LEDs), $\mathrm{B}_{50}+\mathrm{G}_{50}, \mathrm{~B}_{50}+\mathrm{R}_{50}, \mathrm{~B}_{25}+\mathrm{G}_{25}+\mathrm{R}_{50}$, $\mathrm{G}_{50}+\mathrm{R}_{50}$, and $\mathrm{R}_{100}$. All treatments that delivered $\mathrm{R}$ light were delivered equally by the two types of R LEDs. The intensity of each LED type was adjusted according to an average of six measurements from a spectroradiometer (PS-200; StellarNet, Inc., Tampa, FL) made at the seedling tray level at different horizontal positions inside each module. To provide a more uniform light intensity within each module, wire mesh was placed in the middle two-thirds of the chamber, just below the LEDs. In a separate growth chamber, plants were grown under cool-white fluorescent lamps (F96T12; Philips, Amsterdam, The Netherlands) with the same $P P F$ and temperature set points, which served as a control. Plant trays were randomly rear- ranged daily to reduce any positional effects inside each module or chamber. Once treatments were set, the spectral quality of the light treatments was measured again at six positions in each treatment with the spectroradiometer (Fig. 1). Plants were grown under an 18 -h photoperiod (0500 to $2300 \mathrm{HR}$ ) as controlled by a data logger (CR10; Campbell Scientific, Logan, UT) and the growth chambers were set at $20{ }^{\circ} \mathrm{C}$. In each treatment, infrared (IR) sensors (Type K, OS36-01; Omega Engineering, Stamford, CT) that pointed at a downward angle toward the closest tray of plants measured canopy temperature, and shielded thermocouples $(0.13-\mathrm{mm}$ Type E; Omega Engineering) at plant level measured air temperature. In addition, quantum sensors (LI-COR, Lincoln, NE) placed in the middle of each treatment at plug tray level measured light intensity. The IR sensors, thermocouples, and quantum sensors were connected to the same data logger and recorded data every $10 \mathrm{~s}$. The data logger recorded means every 10 min throughout the duration of the experimental replications (Table 1). Plants were irrigated as needed by subsurface irrigation with distilled water supplemented with a water-soluble fertilizer providing (in $\left.\mathrm{mg} \cdot \mathrm{L}^{-1}\right) 50$ nitrogen;, 19 phosphorus; 50 potassium; 23 calcium; 4 magnesium; 1 iron; 0.5 manganese, zinc, and copper; 0.3 boron; and 0.1 molybdenum (MSU Plug Special; GreenCare Fertilizers, Inc., Kankakee, IL).

Data collection and statistical analysis. The experiment was performed twice. Ten random plants of each species and treatment were harvested per replication the following number of days after seed sow (Replications 1, 2): tomato $(32,31)$, impatiens $(33,32)$, petunia $(34,35)$, and salvia $(36,36)$. The variation in harvest time was the result of different growth rates among crops (e.g., salvia develops slower than tomato). The following data were collected at harvest to capture growth attributes: leaf number on the primary stem, total leaf area [measured with a leaf area meter (LI-3000; LI-COR)], fresh shoot weight (using a Mettler Toledo PG5002 scale, Columbus, $\mathrm{OH}$ ), dry shoot weight (after plants were dried in an oven at $66^{\circ} \mathrm{C}$ or greater for $5 \mathrm{~d}$ or longer and using the same scale), and macroscopic flower bud number. A visible leaf that was $25 \%$ or greater unfolded was counted 
in leaf node number. Stem length was measured by a ruler (from the medium surface to the apical meristem) on all plants except for petunia, which grew as a rosette. The number of leaflets with intumescences was counted on tomato; there were no intumescences on the other plants. Tomato was also subjectively evaluated for chlorosis by assignment of a score from 1 (most severe, 100\% yellow) to 5 (no chlorosis, $100 \%$ green). Chlorophyll concentration was determined as reported by Wollaeger and Runkle (2013) 29 or 30 d after seed sow for Replication 1 or 2, respectively. The absorbance of each sample was measured against the blank (dimethylsulfoxide) at 645 and $663 \mathrm{~nm}$ with a spectrophotometer (Hitachi U-3000, Tokyo, Japan).

Data were pooled and analyzed with SAS (SAS Institute, Cary, NC) means procedure (PROC MEANS), mixed model procedure (PROC MIXED), general linear mixed model procedure (PROC GLIMMIX; Poisson distribution for count data) with the pdmix 800 program (Arnold M. Saxton, University of Tennessee) that provided pairwise comparisons between treatments by using Tukey's honestly significant test at $P \leq 0.05$.

\section{Results}

In all species, the mean leaf number was similar among treatments and was 8.6, 9.6,
5.3, and 10.1 for impatiens, salvia, tomato, and petunia, respectively (Fig. 2). Total leaf area was generally the greatest under the fluorescent lamps, the $\mathrm{R}_{100}$ treatment, or both. Plants grown under $\mathrm{R}_{100}$ had $55 \%$ to $114 \%, 47 \%$ to $88 \%, 49 \%$ to $101 \%$, and $57 \%$ to $130 \%$ greater leaf area for impatiens, salvia, tomato, and petunia, respectively, compared with that of those grown with $25 \%$ or greater B light. Leaf area of plants grown under fluorescent lighting was similar to that of plants grown under $R_{100}$ for all species except tomato, in which the leaf area was $8 \%$ less. Tomato grown under $\mathrm{B}_{50}+\mathrm{G}_{50}$ had a greater leaf area than plants under treatments $\mathrm{B}_{25}+\mathrm{G}_{25}+\mathrm{R}_{50}$, and $\mathrm{B}_{50}+\mathrm{R}_{50}$ and had relatively small leaves when grown under treatment $\mathrm{B}_{50}+\mathrm{R}_{50}$.

Height was greatest for impatiens, tomato, and salvia under the $\mathrm{R}_{100}$ treatment. Impatiens, tomato, and salvia grown under $25 \%$ or greater B light were $47 \%$ to $53 \%, 46 \%$ to $50 \%$, or $41 \%$ to $57 \%$ shorter, respectively, than all plants grown under $\mathrm{R}_{100}$. Plants grown under treatment $\mathrm{G}_{50}+\mathrm{R}_{50}$ were of similar height to those grown under fluorescent light but were $23 \%$, $21 \%$, or $27 \%$ shorter for impatiens, tomato, and salvia, respectively, than those grown under $\mathrm{R}_{100}$. Impatiens, tomato, and salvia grown under treatment $\mathrm{G}_{50}+\mathrm{R}_{50}$ were $45 \%$ to $64 \%, 42 \%$ to $56 \%$, or $24 \%$ to $72 \%$ taller, respectively, than all plants grown with $25 \%$ or greater $B$ light. Salvia grown under treatments $\mathrm{B}_{25}+\mathrm{G}_{25}+\mathrm{R}_{50}$ and $\mathrm{B}_{50}+\mathrm{R}_{50}$ were the shortest.

Fresh shoot weight was generally greatest under the fluorescent and $R_{100}$ treatments (Fig. 3). Plants grown under $\mathrm{R}_{100}$ had a fresh weight similar to that of those grown under fluorescent light for all species except tomato. Tomato, salvia, and petunia grown under $\mathrm{R}_{100}$ had $54 \%$ to $83 \%, 48 \%$ to $87 \%$, or $58 \%$ to $112 \%$ greater fresh weight, respectively, than plants grown under treatment $\mathrm{G}_{50}+\mathrm{R}_{50}$ or those with $25 \%$ or greater $\mathrm{B}$ light. Impatiens grown under $\mathrm{R}_{100}$ had $43 \%$ to $83 \%$ greater fresh weight than plants grown with $25 \%$ or greater B light. Petunia and salvia grown under all other treatments had similar fresh weights. Tomato grown under fluorescent light had 18\% less fresh weight than those grown under $\mathrm{R}_{100}$ but $31 \%$ to $51 \%$ greater fresh weight than plants grown with $25 \%$ or greater B light. Fresh weight of salvia and petunia under $25 \%$ or $50 \% \mathrm{G}$ light was similar to that of plants grown under treatments that contained B light.

Dry shoot weight was greatest for tomato and salvia under the $\mathrm{R}_{100}$ treatment and for petunia under $\mathrm{R}_{100}$ or fluorescent light. Tomato and salvia grown under the $\mathrm{R}_{100}$ treatment had $54 \%$ to $86 \%$ and $61 \%$ to $109 \%$
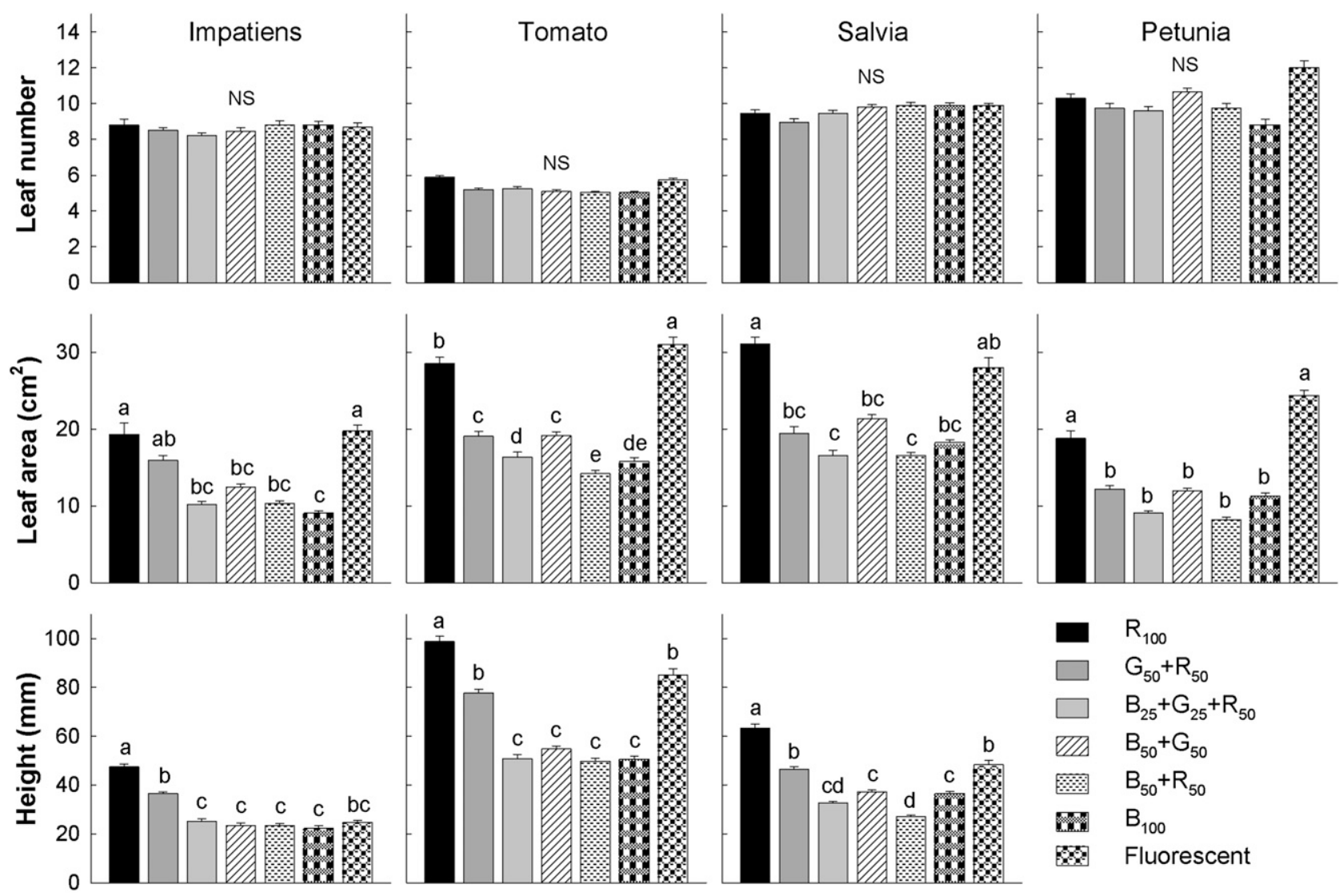

Light quality treatment

Fig. 2. Mean leaf number, leaf area, and height of seedlings $(n=20)$ of four species grown for 31 to $36 \mathrm{~d}$ under six light-quality treatments delivered by lightemitting diodes (LEDs) $(\mathrm{B}=$ blue; $\mathrm{G}=$ green; $\mathrm{R}=$ red) or one treatment delivered by cool-white fluorescent lamps at the same photosynthetic photon flux $(P P F)$. The subscript values after each LED type represent their percentages of the total $P P F$. Means sharing a letter are not statistically different by Tukey's honestly significant difference at $P \leq 0.05$. Error bars indicate SE. 

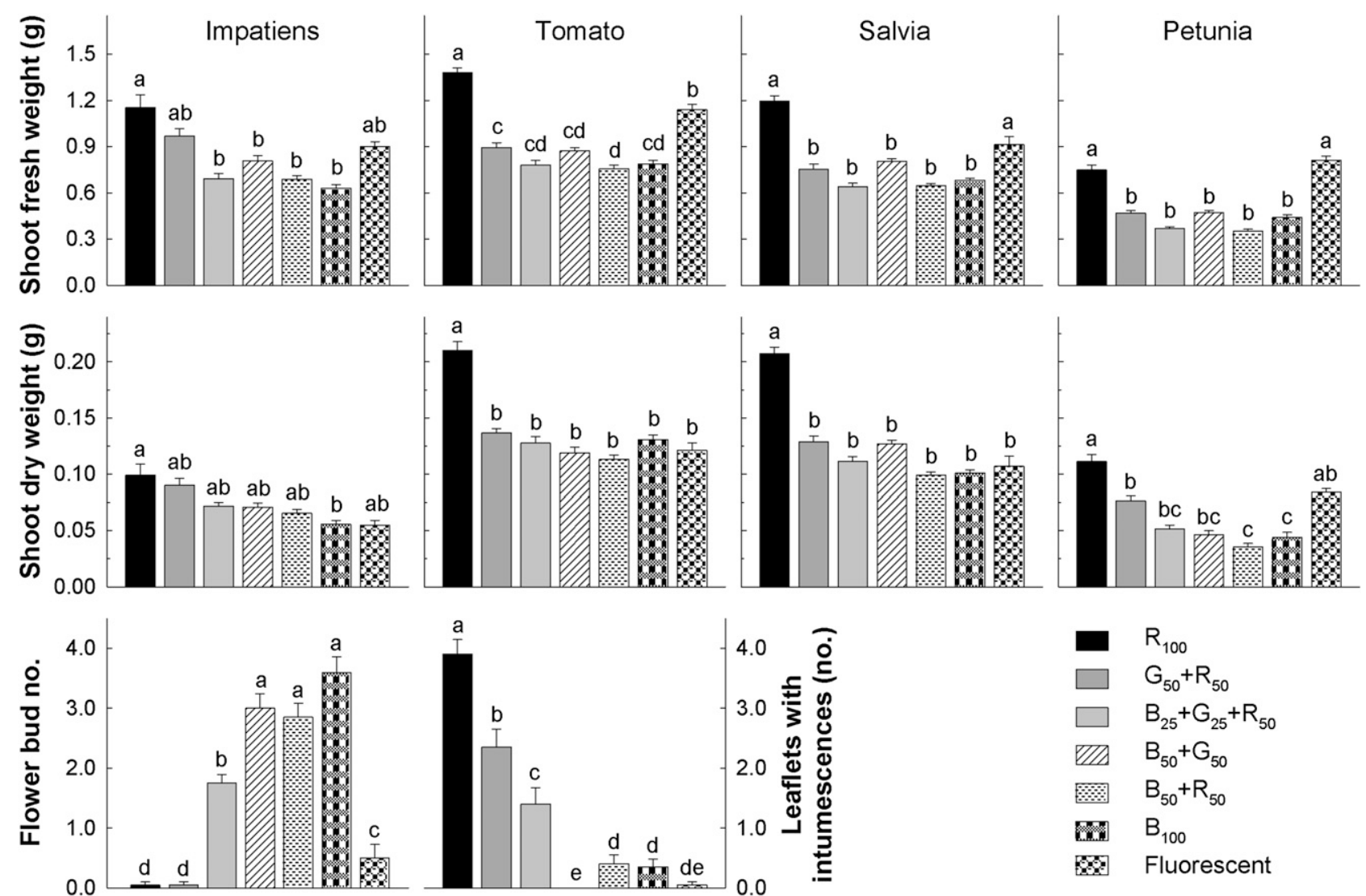

\section{Light quality treatment}

Fig. 3. Mean fresh and dry shoot weights for seedlings $(n=20)$ of four species, impatiens flower bud number, and number of tomato leaflets exhibiting intumescences under six light-quality treatments delivered by light-emitting diodes (LEDs) ( $\mathrm{B}=$ blue; $\mathrm{G}=$ green; $\mathrm{R}=$ red) or one treatment delivered by coolwhite fluorescent lamps at the same photosynthetic photon flux $(P P F)$ after 31 to $36 \mathrm{~d}$. The subscript values after each LED type represent their percentages of the total $P P F$. Means sharing a letter are not statistically different by Tukey's honestly significant difference at $P \leq 0.05$. Error bars indicate sE.

greater dry weight, respectively, than plants grown under all other treatments. Impatiens grown under $\mathrm{B}_{100}$ light had $44 \%$ less dry weight compared with those grown under $\mathrm{R}_{100}$, but all other treatments had statistically similar dry weight. Compared with that in the $\mathrm{G}_{50}+\mathrm{R}_{50}$ treatment, dry weight of petunia was $45 \%$ greater under the $\mathrm{R}_{100}$ treatment and $63 \%$ to $71 \%$ lower under the $B_{50}+R_{50}$ or $\mathrm{B}_{100}$ treatment.

Impatiens was the only plant that had visible flower buds at the end of the treatments. Impatiens grown under $50 \%$ or greater B light had $63 \%$ to $106 \%$ more flower buds on average than those grown under treatment $\mathrm{B}_{25}+\mathrm{G}_{25}+$ $\mathrm{R}_{50}$. Plants grown under fluorescent light developed $250 \%$ fewer flower buds on average than those grown under treatment $\mathrm{B}_{25}+\mathrm{G}_{25}+$ $\mathrm{R}_{50}$. Impatiens grown without $\mathrm{B}$ light had the fewest flower buds. Tomato developed the most leaflets with intumescences when grown under $\mathrm{R}_{100}$ light, whereas intumescences were absent or nearly absent when plants were grown under the $B_{50}+G_{50}$ or the fluorescent lighting treatment. Plants under the treatment $\mathrm{G}_{50}+\mathrm{R}_{50}$ developed $40 \%$ fewer leaflets with intumescences than those under $\mathrm{R}_{100}$ but $68 \%$ more leaflets with intumescences than plants under the $\mathrm{B}_{25}+\mathrm{G}_{25}+\mathrm{R}_{50}$ treatment.

The concentration of chlorophyll was similar among all treatments for impatiens and petunia (Fig. 4). However, in salvia and tomato, it was relatively high under fluorescent light and relatively low under all other treatments except salvia under treatments $\mathrm{R}_{100}$ and $\mathrm{B}_{50}+\mathrm{G}_{50}$ and tomato under the $\mathrm{B}_{50}+\mathrm{G}_{50}$ treatment. Tomato grown without B light developed more chlorosis (2 to 3 points lower on the chlorosis scale) than in all other treatments.

\section{Discussion}

The primary objective of our experiment was to quantify growth characteristics of seedlings grown under different ratios of B, $\mathrm{G}$, and $\mathrm{R}$ light while all other environmental characteristics, including the $P P F$, were constant. In our study, leaf area was $47 \%$ to $130 \%$ greater in plants grown under the $R_{100}$ treatment compared with those grown with $25 \%$ or greater B light. Several studies (Eskins, 1992; Lee et al., 2011; Ohashi-Kaneko et al., 2007) reported similar results: plants grown under $\mathrm{R}$ light had a greater leaf area than when grown under a majority of, or only, B light. For example, leaf area of Arabidopsis irradiated at a $P P F$ of $50 \mu \mathrm{mol} \cdot \mathrm{m}^{-2} \cdot \mathrm{s}^{-1}$ was approximately two times greater when grown under only $\mathrm{R}$ fluorescent light than when the spectrum included 60\% B light (Eskins, 1992). In a separate study, lettuce, spinach, and komatsuna
(Brassica campestris) were grown at a $P P F$ of $300 \mu \mathrm{mol} \cdot \mathrm{m}^{-2} \cdot \mathrm{s}^{-1}$ from R, B, and white fluorescent lamps (Ohashi-Kaneko et al., 2007). Lettuce had a $44 \%$ greater leaf area under $\mathrm{R}$ light than under $\mathrm{B}$ light, but it was similar under $\mathrm{R}, \mathrm{R}+\mathrm{B}$, or white light. Spinach, in contrast, had a $192 \%$ greater leaf area under $R$ + B compared with only B light. In contrast to our results with four specialty crops, leaf area of marigold (Tagetes erecta) grown at a $P P F$ of $90 \mu \mathrm{mol} \cdot \mathrm{m}^{-2} \cdot \mathrm{s}^{-1}$ was $20 \%$ greater under $\mathrm{R}+\mathrm{B}$ LEDs than under white fluorescent light (Heo et al., 2006).

Plants grown under only R light typically accumulate more biomass than when grown under additional wavebands of photosynthetic light at the same $P P F$. In our study, the shade-intolerant plants tomato, salvia, and petunia grown without $\mathrm{B}$ or $\mathrm{G}$ light had $48 \%$ to $112 \%$ greater fresh shoot weight than plants grown under treatments with $25 \%$ or greater B or $50 \% \mathrm{G}$ light. Similar results occurred in the shade-tolerant impatiens. Tomato grown under fluorescent light had $18 \%$ less fresh shoot weight than those grown under only $\mathrm{R}$ light, whereas all other plant species in our study had similar fresh shoot weights between the two treatments. Our results were consistent with those reported for four cultivars of spinach and Arabidopsis (Eskins, 1992; Li et al., 2011). Similar to 
tomato, komatsuna had $43 \%$ greater dry weight under R light than white light (Ohashi-Kaneko et al., 2007). In contrast, rice (Oryza sativa) plants had $\approx 25 \%$ greater biomass under a combination of $\mathrm{R}$ (peak $\approx 660 \mathrm{~nm}$ ) and $\mathrm{B}$ (peak $\approx 460 \mathrm{~nm} ; \mathrm{R}: \mathrm{B}=4: 1$ ) LEDs compared with $\mathrm{R}$ LEDs alone at a $P P F$ of $380 \mu \mathrm{mol} \cdot \mathrm{m}^{-2} \cdot \mathrm{s}^{-1}$ (Ohashi-Kaneko et al., 2006). The conflicting results could be attributed to the differences in peak wavelength of the B LEDs, which differed by $14 \mathrm{~nm}$ from that of ours, and the $P P F$ was more than twice that used in this study. Also in contrast to our results, lettuce had $28 \%$ greater shoot dry weight under white light compared with only $\mathrm{R}$ light at a $P P F$ that was $88 \%$ greater than ours (Ohashi-Kaneko et al., 2007). These differences in results suggest that the effect of light quality on plant growth is highly species-specific and could depend on light intensity.

The use of G light in biomass accumulation varies with crop species and depends on its relative proportion to the total spectrum. In contrast to results with lady slipper orchid (Lee et al., 2011) and lettuce (Kim et al., 2004), plants in our study had similar fresh weights under $25 \%$ or $50 \% \mathrm{G}$ light compared with plants under only B light. Consistent with results reported for cherry tomato (Liu et al., 2011b), plants under different combinations of $\mathrm{R}$ and $\mathrm{B}$ light with or without the addition of $\mathrm{G}$ light had similar shoot fresh or dry weights. Therefore, our results indicate that $25 \% \mathrm{G}$ light can substitute for $25 \%$ B light without influencing biomass accumulation, at least for the crops grown and at the $P P F$ provided.

Compact growth is often a desirable characteristic in young specialty plant production. Including B light in photosynthetic lighting could be used to produce relatively short plants. In this study, impatiens, tomato, and salvia grown under $25 \%$ or greater B light were $41 \%$ to $57 \%$ shorter than plants grown under only $\mathrm{R}$ light. Plants grown under treatment $\mathrm{G}_{50}+\mathrm{R}_{50}$ were of similar height to those grown under fluorescent light. Phytochrome and cryptochrome, which are photoreceptors that primarily detect and respond to the $\mathrm{R}$ to far-red (FR) ratio or B light, respectively, mediate extension growth of plants (Cashmore et al., 1999; Lin, 2000; Sellaro et al., 2010; Smith, 2000). When both a high R:FR ratio and B light are present in the light environment, they synergistically suppress stem elongation to a greater extent than if only one or the other was present (Casal and Mazzella, 1998; Hennig et al., 1999; Sellaro et al., 2010; Smith, 2000). Phytochrome also absorbs ultraviolet and B light, although to a lesser extent than R or FR light. We estimated the phytochrome photoequilibrium $\left(\mathrm{P}_{\mathrm{FR}} / \mathrm{P}_{\mathrm{R}+\mathrm{FR}}\right)$ of plants in each lighting treatment according to Sager et al. (1988) using the spectra in Figure 1. Treatments with $50 \%$ or greater $\mathrm{R}$ light from LEDs or fluorescent lamps had a similar estimated $\mathrm{P}_{\mathrm{FR}} / \mathrm{P}_{\mathrm{R}+\mathrm{FR}}$ of 0.85 to 0.89 , yet plants under treatments with $25 \%$ or $50 \%$ B light had appreciably less extension growth. The LED treatments without $\mathrm{R}$ light had a lower $\mathrm{P}_{\mathrm{FR}} /$ $\mathrm{P}_{\mathrm{R}+\mathrm{FR}}$, yet extension growth was less than that with a higher $\mathrm{P}_{\mathrm{FR}} / \mathrm{P}_{\mathrm{R}+\mathrm{FR}}$, which contradicts the typical phytochrome response. Therefore, the extension growth responses cannot be attributed to phytochrome. Although extremely low-fluence B light $(0.1$ $\left.\mu \mathrm{mol} \cdot \mathrm{m}^{-2} \cdot \mathrm{s}^{-1}\right)$ can stimulate phototropins and cause an increase in extension growth, our treatments had a minimum of $10 \mu \mathrm{mol} \cdot \mathrm{m}^{-2} \cdot \mathrm{s}^{-1}$ of B light, so phototropins were likely not involved. Therefore, the stem elongation inhibition in this study can likely be attributed to the B light-stimulated cryptochrome receptors (Liu et al., 2011a; Takemiya et al., 2005; Wang et al., 2013).

Maximal cryptochrome activity is stimulated by wavebands from 390 to $480 \mathrm{~nm}$, although to some extent, cryptochrome-like responses can still be activated by wavelengths up to $550 \mathrm{~nm}$ (Ahmad et al., 2002). In Arabidopsis, CRY1 genes regulate the deetiolation of seedlings by altering gene expression and transcription of those downstream such as COP1 and HY5, respectively (Jiao et al., 2007; Liu et al., 2011a; Yang et al., 2005). These genes subsequently regulate the signaling of phytohormones such as auxin, brassinosteroid, and gibberellic acid (GA) (Liu et al., 2011a). For example, sorghum (Sorghum bicolor) mutant harl had increased DELLA (GA repressor) expression and lower bioactive concentrations of GA when irradiated with $15 \mu \mathrm{mol} \cdot \mathrm{m}^{-2} \cdot \mathrm{s}^{-1}$ of B LED (peak = $470 \mathrm{~nm}$ ) light compared with those under 2 $\mu \mathrm{mol} \cdot \mathrm{m}^{-2} \cdot \mathrm{s}^{-1}$ of FR (peak $\left.=740 \mathrm{~nm}\right) \mathrm{LED}$ light (Gao et al., 2012). On external GA application, cell elongation and stem elongation were restored, which suggested that B light up-regulates DELLA proteins, which in turn decreases GA biosynthesis (Gao et al., 2012). Numerous studies with whole plants have reported B light inhibition of extension growth (Liu et al., 2011b; Runkle and Heins, 2001). For example, cherry tomatoes grown under B or R + G + B LEDs were $33 \%$ or $49 \%$ shorter, respectively, than plants grown under R LEDs (Liu et al., 2011b). Likewise, petioles of strawberry (Fragaria $\times$ ananassa) grown under $\mathrm{R}+\mathrm{B}(1: 1$; peak $=660,450 \mathrm{~nm})$ or B LED light at a $P P F$ of $45 \mu \mathrm{mol} \cdot \mathrm{m}^{-2} \cdot \mathrm{s}^{-1}$ were $10 \%$ or $22 \%$ shorter, respectively, than plants grown under only R light (Nhut et al., 2003).

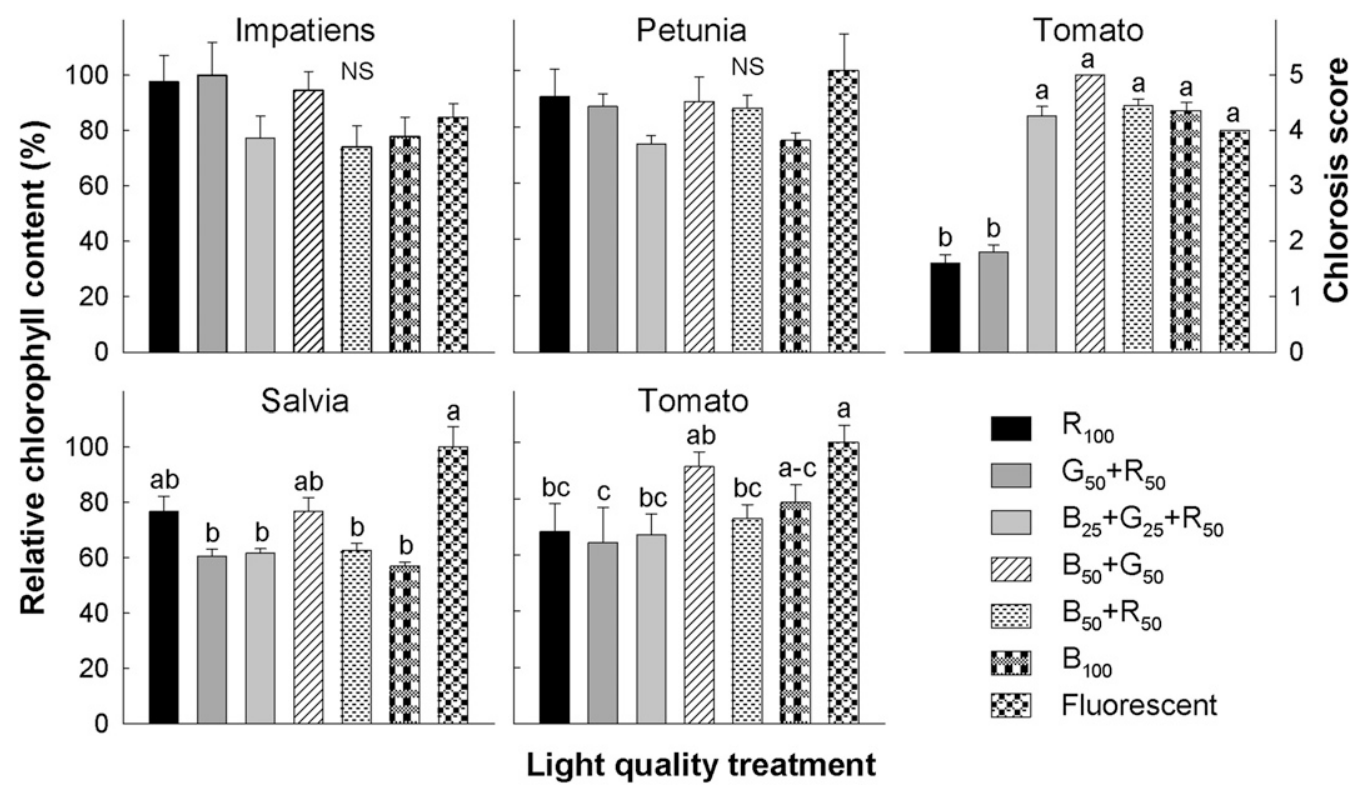

Fig. 4. Chlorophyll concentration relative to that for the greatest treatment for seedlings $(n=20)$ of four species and chlorosis score $(1=$ most chlorotic; $5=$ least chlorotic) for tomato grown for 31 to $36 \mathrm{~d}$ under six light-quality treatments delivered by light-emitting diodes (LEDs) $(B=b l u e ; G=g r e e n ; R=$ red) or one treatment delivered by cool-white fluorescent lamps at the same photosynthetic photon flux $(P P F)$. The subscript values after each LED type represent their percentages of the total $P P F$. Means sharing a letter are not statistically different by Tukey's honestly significant difference at $P \leq 0.05$. Error bars indicate sE. 
Cryptochrome-mediated stem extension suppression is stimulated by wavebands up to $550 \mathrm{~nm}$, whereas longer waveband radiation $(570$ to $600 \mathrm{~nm})$ can have the opposite effect (Ahmad et al., 2002; Sellaro et al., 2010). Longer waveband $G$ light can act similar to FR light and even cause shadeavoidance symptoms (e.g., elongated petioles, leaf hyponasty, early flowering) through cry and also through a cryptochromeindependent receptor not yet identified (Folta and Maruhnich, 2007; Wang and Folta, 2013; Zhang et al., 2011). Studies have suggested a new class of photoreceptors such as cyanochromes (which are in cyanobacteria); however, their presence or the presence of another unidentified receptor remains unclear (Ulijasz et al., 2009; Wang and Folta, 2013). In addition, the duration, peak wavelength, and intensity of $\mathrm{G}$ light as well as its intensity relative to other wavebands affect plant physiological responses (Bouly et al., 2007; Folta and Maruhnich, 2007; Lin et al., 1996; Wang and Folta, 2013). A short pulse of G light can reverse the $B$ light inhibition of stem elongation by stimulating the cry receptors (Bouly et al., 2007; Folta and Maruhnich, 2007). For example, Arabidopsis had up to a $30 \%$ increase in stem elongation when $100 \mu \mathrm{mol} \cdot \mathrm{m}^{-2} \cdot \mathrm{s}^{-1}$ of G LED (peak $=525 \mathrm{~nm}$ ) light was delivered as a pulse to low-fluence (less than $4 \mu \mathrm{mol} \cdot \mathrm{m}^{-2} \cdot \mathrm{s}^{-1}$ ) $\mathrm{R}($ peak $=630 \mathrm{~nm})$ and $\mathrm{B}($ peak $=470 \mathrm{~nm})$ LED light (Folta, 2004). However, all of our treatments that included $\mathrm{G}$ light also delivered a relatively high intensity of B or R light (25 $\mu \mathrm{mol} \cdot \mathrm{m}^{-2} \cdot \mathrm{s}^{-1}$ or greater), which could have overcome any independent effects of G light (Lin et al., 1996; Wang and Folta, 2013). Therefore, in our study, seedling stems elongated similarly with or without $\mathrm{G}$ light when B light was also provided.

The peak wavelength of $\mathrm{G}$ light influences the relative amount of cryptochrome stimulation. For example, lettuce grown under $300 \mu \mathrm{mol} \cdot \mathrm{m}^{-2} \cdot \mathrm{s}^{-1}$ of G LED light with peak $=$ $510 \mathrm{~nm}$ had $\approx 55 \%$ greater dry mass than plants grown under peak wavelengths at 520 or $530 \mathrm{~nm}$ (Johkan et al., 2012). Any fluence rate of $\mathrm{G}$ light over $10 \mu \mathrm{mol} \cdot \mathrm{m}^{-2} \cdot \mathrm{s}^{-1}$ had an inhibitory effect on stem elongation (Wang et al., 2013). Consistent with that paradigm, all four species in our study under treatment $50 \% \mathrm{G}$ light $\left(80 \mu \mathrm{mol} \cdot \mathrm{m}^{-2} \cdot \mathrm{s}^{-1}\right.$ with peak $=$ $519 \mathrm{~nm}$ ) with $50 \% \mathrm{R}$ light had a stem height shorter than that of plants under only $\mathrm{R}$ light and taller than that of plants under treatments with B light. This suggests that $G$ light stimulated cryptochrome responses, but to a lesser extent than treatments with B light, because the peak of our G LEDs was greater than wavelengths that elicit maximal cryptochrome activity (390 to $480 \mathrm{~nm}$ ) (Ahmad et al., 2002).

In some situations, early flowering can be desirable in young plant production, whereas in other cases, it is not. Altering the spectra of $\mathrm{B}, \mathrm{R}$, or FR light can influence flower induction (Cerdán and Chory, 2004; Lin, 2000). Impatiens in our study produced $82 \%$ fewer flower buds under fluorescent lighting than under treatment $\mathrm{B}_{50}+\mathrm{R}_{50}$. Furthermore, impatiens grown under 100\% B light had 71 times more flower buds than those grown under only $\mathrm{R}$ light. Marigold and salvia produced $43 \%$ or $100 \%$ more flower buds, respectively, under $\mathrm{B}+\mathrm{R}$ (peaks $=440$ and $650 \mathrm{~nm}$ ) LED light compared with those grown under fluorescent light at a $P P F$ of $90 \mu \mathrm{mol} \cdot \mathrm{m}^{-2} \cdot \mathrm{s}^{-1}$ (Heo et al., 2006), results similar to ours. However, ageratum (Ageratum houstonianum) produced 50\% more flower buds under fluorescent light than under the $\mathrm{R}+\mathrm{B}$ light treatment. In a similar study, marigold and salvia grown under $\mathrm{B}$ or $\mathrm{R}$ LEDs developed a similar number of flower buds but $77 \%$ to $86 \%$ fewer than those under fluorescent lamps (Heo et al., 2002). An increase in flower bud number with increasing B light could be attributed to CRY2 cryptochrome activity. CRY2 degradation regulates the photoperiodic flowering response and acts on downstream genes, including $C O$ and $F T$ (Chaves et al., 2011; El-Assal et al., 2003). Most CRY2 mutants were developed in photoperiodic (e.g., Arabidopsis) species (Lin, 2000); therefore, it is not known whether CRY2 also influences flowering in day-neutral plants such as impatiens.

Edema or intumescences have been associated with plants grown in R-dominant environments with little or no B or FR light, ultraviolet-B (280 to $315 \mathrm{~nm}$ ) radiation, or high humidity, especially those in Solanaceae (Lang and Tibbitts, 1983; Massa et al., 2008; Morrow and Tibbitts, 1988; Nilsen, 1971). In our study, tomato developed the most leaflets with intumescences on plants grown under only $\mathrm{R}$ light, whereas intumescences were absent or nearly absent when plants were grown under the $B_{50}+G_{50}$ or fluorescent lighting treatment. The fluorescent treatment delivered $31 \mu \mathrm{mol} \cdot \mathrm{m}^{-2} \cdot \mathrm{s}^{-1}$ of $\mathrm{B}$ light and less than $5 \mu \mathrm{mol} \cdot \mathrm{m}^{-2} \cdot \mathrm{s}^{-1}$ of ultraviolet-A radiation. Plants under the treatment $\mathrm{G}_{50}+\mathrm{R}_{50}$ developed $40 \%$ fewer leaflets with intumescences than those under $\mathrm{R}_{100}$. Similarly, wild tomato (L. hirsutum) developed intumescences on 63 or $3 \%$ of the sampled leaf area surface when under $\mathrm{R}$ or $G$ fluorescent lamps, respectively, whereas it was absent under B fluorescent lamps at a $P P F$ of $25 \mu \mathrm{mol} \cdot \mathrm{m}^{-2} \cdot \mathrm{s}^{-1}$ (Morrow and Tibbitts, 1988).

Several studies have reported greater chlorophyll concentrations in leaves under $\mathrm{B}$ light compared with those under $\mathrm{R}$ light (Hogewoning et al., 2010). However, chlorophyll concentration of impatiens and petunia in our study was similar under the lighting treatments, which was similar to that reported in cherry tomato and lettuce ( $\mathrm{Li}$ and Kubota, 2009; Liu et al., 2011b). Salvia and tomato chlorophyll concentration was relatively high under fluorescent light, whereas it was relatively low under all other treatments except in plants grown under treatments $\mathrm{R}_{100}$ and $\mathrm{B}_{50}+$ $\mathrm{G}_{50}$ light for salvia and $\mathrm{B}_{50}+\mathrm{G}_{50}$ for tomato. Similarly, rice had greater concentrations of chlorophyll under a combination of $\mathrm{R}$ and $\mathrm{B}$ LEDs compared with R LEDs alone (OhashiKaneko et al., 2006). Likewise, cucumber (Cucumis sativus) under ratios of $\mathrm{R}$ (peak = $638 \mathrm{~nm})$ and $\mathrm{B}$ (peak $=450 \mathrm{~nm})$ LEDs at a $P P F$ of $100 \mu \mathrm{mol} \cdot \mathrm{m}^{-2} \cdot \mathrm{s}^{-1}$ had increasing chlorophyll content per unit leaf area with increasing percentages of $\mathrm{B}$ light (Hogewoning et al., 2010). However, percentage of chlorophyll per gram of dry mass was similar among plants that received $15 \%$ or greater B light. Similar to our results with impatiens and petunia, chlorophyll content per leaf area of cherry tomato was similar among treatments delivering $\mathrm{B}, \mathrm{G}$, and $\mathrm{R}$ light, alone or combined (Liu et al., 2011b). Chlorophyll content of lettuce was also similar among combinations of cool-white fluorescent and R (peak = $658 \mathrm{~nm}$ ) or B (peak $=476 \mathrm{~nm})$ LED light at a $P P F$ of $300 \mu \mathrm{mol} \cdot \mathrm{m}^{-2} \cdot \mathrm{s}^{-1}$ ( $\mathrm{Li}$ and Kubota, 2009). These results collectively indicate that in some plants, light quality influences chlorophyll biosynthesis, degradation, or both, whereas in other plants, such responses are apparently limited.

Our results describe the growth and acclimation of a plant to mixtures of $B, G$, and $R$ light at one fluence rate and, given their similar responses among the species studied, can probably be extrapolated to other crops. Irradiating plants such as microgreens or herbs with only $\mathrm{R}$ light may yield plants with desired crop-specific attributes such as increased biomass and leaf size. For the production of ornamental transplants in an enclosed environment, B light suppresses extension growth and yields compact plants, which is often a desirable attribute. Further research will need to examine other combinations of these wavelengths at different fluence rates and on other commercially important bedding plant species. In addition, future research could examine the concentrations of other compounds such as anthocyanins, which can be an indicator of quality in certain ornamental crops such as purple fountain grass (Pennisetum setaceum 'Rubrum') or kale (Brassica oleracea).

\section{Literature Cited}

Ahmad, M., N. Grancher, M. Heil, R.C. Black, B Giovani, P. Galland, and D. Lardemer. 2002. Action spectrum for cryptochrome-dependent hypocotyl growth inhibition in Arabidopsis. Plant Physiol. 129:774-785.

Bouly, J.P., E. Schleicher, and M. Dionisio-Sese. 2007. Cryptochrome blue-light photoreceptors are activated through interconversion of flavin redox states. J. Biol. Chem. 282:9383-9391.

Bourget, M.C. 2008. An introduction to lightemitting diodes. HortScience 43:1944-1946.

Casal, J.J. and M.A. Mazzella. 1998. Conditional synergism between cryptochrome 1 and phytochrome B is shown by the analysis of phyA, phy $B$ and hy 4 simple, double and triple mutants in Arabidopsis. Plant Physiol. 118:19-25.

Cashmore, A.R., J.A. Jarillo, Y.J. Wu, and D. Liu. 1999. Cryptochromes: Blue light receptors for plants and animals. Science 284:760-765.

Cerdán, P.D. and J. Chory. 2004. Regulation of flowering time by light quality. Nature 423:881885

Chaves, I., R. Pokorny, M. Byrdin, N. Hoang, T. Ritz, K. Brettel, L.-O. Essen, G.T.J. van der Horst, A. Batschauer, and M. Ahmad. 2011. The cryptochromes: Blue light photoreceptors in plants and animals. Annu. Rev. Plant Biol. 62:335-364. 
Cosgrove, D.J. 1981. Rapid suppression of growth by blue light. Plant Physiol. 67:584-590.

Doukas, D. and C.C. Payne. 2007. Greenhouse whitefly (Homoptera: Aleyrodidae) dispersal under different UV-light environments. J. Econ. Entomol. 100:389-397.

El-Assal, S.E.D., C. Alonso-Blanco, A.J.M. Peeters, C. Wagemaker, J.L. Weller, and M. Koornneef. 2003. The role of cryptochrome 2 in flowering in Arabidopisis. Plant Physiol. 133:1504-1516.

Eskins, K. 1992. Light-quality effects of Arabidopsis development. Red, blue, and far-red regulation of flowering and morphology. Physiol. Plant. 86: 439-444.

Folta, K.M. 2004. Green light stimulates early stem elongation, antagonizing light-mediated growth inhibition. Plant Physiol. 135:1407-1416.

Folta, K.M. and S.A. Maruhnich. 2007. Green light: A signal to slow down or stop. J. Expt. Bot. 58:3099-3111.

Fukuda, N., M. Fujita, Y. Ohta, S. Sase, S. Nishimura, and H. Ezura. 2008. Directional blue light irradiation triggers epidermal cell elongation of abaxial side resulting in inhibition of leaf epinasty in geranium under red light conditions. Sci. Hort. 115:176-182.

Fukuda, N., H. Ikeda, and M. Nara. 1993. Effects of light quality on the growth of lettuce and spinach cultured by hydroponics under controlled environment. Agr. Struct. 24:23-30.

Gao, S., X. Xie, S. Yang, Z. Chen, and X. Wang. 2012. The changes of GA level and signaling are involved in the regulation of mesocotyl elongation during blue light mediated de-etiolation in Sorghum bicolor. Mol. Biol. Rpt. 39:40914100 .

Goins, G.D., N.C. Yorio, M.M. Sanwo, and C.S. Brown. 1997. Photomorphogenesis, photosynthesis, and seed yield of wheat plants grown under red light-emitting diodes (LEDs) with and without supplemental blue lighting. J. Expt. Bot. 48:1407-1413.

Hemming, S. 2011. Use of natural and artificial light in horticulture - Interaction of plant and technology. Acta Hort. 907:25-35.

Hennig, L., M. Funk, G.C. Whitelam, and E. Schäfer. 1999. Functional interaction of cryptochrome 1 and phytochrome D. Plant J. 20:289294.

Heo, J., C. Lee, D. Chakrabarty, and K. Paek. 2002. Growth responses of marigold and salvia bedding plants as affected by monochromatic or mixture radiation provided by light-emitting diode (LED). Plant Growth Regulat. 38:225230.

Heo, J.W., C.W. Lee, and K.Y. Paek. 2006. Influence of mixed LED radiation on the growth of annual plants. J. Plant Biol. 49:286-290.

Hogewoning, S.W., G. Trouwborst, H. Maljaars, H. Poorter, W. van Ieperen, and J. Harbinson. 2010. Blue light dose-responses of leaf photosynthesis, morphology, and chemical composition of Cucumis sativus grown under different combinations of red and blue light. J. Expt. Bot. 61:3107-3117.

Imaizumi, T., H.G. Tran, T.E. Swartz, W.R. Briggs, and S.A. Kay. 2003. FKF1 is essential for photoperiodic-specific light signaling in Arabidopsis. Nature 426:302-306.

Jiao, Y., O.S. Lau, and X.W. Deng. 2007. Lightregulated transcriptional networks in higher plants. Nat. Rev. Genet. 8:217-230.

Johkan, M., K. Shoji, F. Goto, S. Hahida, and T. Yoshihara. 2012. Effect of green light wavelength and intensity on photomorphogenesis and photosynthesis in Lactiva sativa. Environ. Expt. Bot. 75:128-133.
Kato, A., Y. Morio, K. Murakami, and K. Nakamura. 2011. Plant growth under white LEDs compared with under fluorescent lamps. Acta Hort. 907:227-232.

Kim, H.-H., G.D. Goins, R.M. Wheeler, and J.C. Sager. 2004. Stomatal conductance of lettuce grown under or exposed to different light qualities. Ann. Bot. (Lond.) 94:691-697.

Kumar, P. and H.M. Poehling. 2006. UV-blocking plastic films and nets influence vectors and virus transmission on greenhouse tomatoes in the humid tropics. Environ. Entomol. 35:10691082.

Lang, S.P. and T.W. Tibbitts. 1983. Factors controlling intumescence development on tomato plants. J. Amer. Soc. Hort. Sci. 108:93-98.

Lee, Y.I., W. Fang, and C.C. Chen. 2011. Effect of six different LED light qualities on the seedling growth of Paphiopedilum orchid in vitro. Acta Hort. 907:389-391.

Li, J., S. Hikosaka, and E. Goto. 2011. Effects of light quality and photosynthetic photon flux on growth and carotenoid pigments in spinach (Spinacia oleracea L.). Acta Hort. 907:105-110.

Li, Q. and C. Kubota. 2009. Effects of supplemental light quality on growth and phytochemicals of baby leaf lettuce. Environ. Exp. Bot. 67:59-64.

Lin, C. 2000. Photoreceptors and regulation of flowering time. Plant Physiol. 123:39-50.

Lin, C., M. Ahmad, and A.R. Cashmore. 1996 Arabidopsis cryptochrome 1 is a soluble protein mediating blue light-dependent regulation of plant growth and development. Plant J. 10:893902.

Liu, X.Y., T.T. Chang, S.R. Guo, Z.G. Xu, and J. Li. 2011a. Effect of light quality of LED on growth and photosynthetic character in cherry tomato seedling. Acta Hort. 907:325-330.

Liu, H., B. Liu, C. Zhao, M. Pepper, and C. Lin. 2011 b. The action mechanisms of plant cryptochromes. Trends Plant Sci. 16:684-691.

Massa, G.D., H.H. Kim, R.M. Wheeler, and C.A. Mitchell. 2008. Plant productivity in response to LED lighting. HortScience 43:1951-1956.

Mitchell, C., A.-J. Both, M. Bourget, J. Burr, C. Kubota, R. Lopez, R. Morrow, and E. Runkle. 2012. LEDs: The future of greenhouse lighting! Chron. Hort. 52:6-11.

Morrow, R.C. 2008. LED lighting in horticulture. HortScience 43:1947-1950.

Morrow, R.C. and T.W. Tibbitts. 1988. Evidence for involvement of phytochrome in tumor development in plants. Plant Physiol. 88:1110 1114.

Nhut, D.T., T. Takamura, H. Watanabe, K. Okamoto, and M. Tanaka. 2003. Responses of strawberry plantlets to cultured in vitro under superbright red and blue light-emitting diodes (LEDs). Plant Cell Tissue Organ Cult. 73:43-52.

Nilsen, K.N. 1971. Plant responses to nearultraviolet light. HortScience 6:26-29.

Ohashi-Kaneko, K., R. Matsuda, E. Goto, K. Fujiwara, and K. Kurata. 2006. Growth of rice plants under red light with or without supplemental blue light. Soil Sci. Plant Nutr. 52:444452.

Ohashi-Kaneko, K., M. Takase, N. Kon, K. Fujiwara, and K. Kurata. 2007. Effect of light quality on growth and vegetable quality in leaf lettuce, spinach, and komatsuna. Envrion. Control Biol. 45:189-198.

Rapisarda, C., G. Tropea, G. Cascone, R. Mazzarella, A. Colombo, and T. Serges. 2006. UV-absorbing plastic films for the control of Bemisia tabaci and tomato yellow leaf curl disease (TYLCD) in protected cultivations in Sicily. Acta Hort. 719:597-604.
Runkle, E.S. and R.D. Heins. 2001. Specific functions of red, far red, and blue light in flowering and stem extension of long-day plants. J. Amer. Soc. Hort. Sci. 126:275-282.

Saebo, A., T. Krekling, and M. Appelgren. 1995. Light quality affects photosynthesis and leaf anatomy of birch plantlets in vitro. Plant Cell Tissue Organ Cult. 41:177-185.

Sager, J.C., W.O. Smith, J.L. Edwards, and K.L. Cyr. 1988. Photosynthetic efficiency and phytochrome photoequilibria determination using spectral data. Trans. Amer. Soc. Agr. Eng. 31: 1882-1889.

Sellaro, R., M. Crepy, S.A. Trupkin, E. Karayekov, A.S. Buchovsky, C. Rossi, and J.J. Casal. 2010. Cryptochrome as a sensor of the blue/green ratio of natural radiation in Arabidopsis. Plant Physiol. 154:401-409.

Smith, H. 2000. Phytochromes and light signal perception by plants-An emerging synthesis. Nature 407:585-591.

Takemiya, A., S.-I. Inoue, M. Doi, T. Kinoshita, and K.-I. Shimazaki. 2005. Phototropins promote plant growth in response to blue light in low light environments. Plant Cell 17:1120-1127.

Tennessen, D.J., E.L. Singsaas, and T.D. Sharkey. 1994. Light-emitting diodes as a light source for photosynthesis research. Photosynth. Res. 39:85-92.

Ulijasz, A.T., G. Cornilescu, D. von Stetten, C. Cornilescu, F.V. Escobar, J. Zhang, R.J. Stankey, M. Rivera, P. Hildebrandt, and R.D. Vierstra. 2009. Cyanochromes are blue/green light photoreversible photoreceptors defined by a stable double cysteine linkage to a phycoviolobilintype chromophore. J. Biol. Chem. 284:2975729772.

van Ieperen, W. 2012. Plant morphological and developmental responses to light quality in a horticultural context. Acta Hort. 956:131-139.

van Ieperen, W. and G. Trouwborst. 2008. The application of LEDs as assimilation light source in greenhouse horticulture: A simulation study. Acta Hort. 801:1407-1414.

Wang, Y. and K.M. Folta. 2013. Contributions of green light to plant growth and development. Amer. J. Bot. 100:70-78.

Wang, Y., S.A. Maruhnich, M.H. Mageroy, J.R. Justice, and K.M. Folta. 2013. Phototropin 1 and cryptochrome action in response to green light in combination with other wavelengths. Planta 237:225-237.

Watanabe, H. 2011. Light-controlled plant cultivation system in Japan-Development of vegetable factory using LEDs as a light source for plants. Acta Hort. 907:37-44.

Weinig, C., K.A. Gravuer, N.C. Kane, and J. Schmitt. 2004. Testing adaptive plasticity to UV: Costs and benefits of stem elongation and light-induced phenolics. Evolution 58:2645-2656.

Wollaeger, H.M. and E.S. Runkle. 2013. Growth responses of ornamental annual seedlings under different wavelengths of red light provided by light-emitting diodes. HortScience 48 : 1478-1483.

Yang, J., R. Lin, J. Sullivan, U. Hoecker, B. Liu, L. Xu, X.W. Deng, and H. Wang. 2005. Light regulates COP1-mediated degradation of HFR1, a transcription factor essential for light signaling in Arabidopsis. Plant Cell 17:804-821.

Yang, Y.T., P. Xiao, and Q.C. Yang. 2011. Effects of LED light quality R/B to growth of sweet potato plantlets in vitro and energy consumptions of lighting. Acta Hort. 907:403-407.

Zhang, T., S.A. Maruhnich, and K.M. Folta. 2011. Green light induces shade avoidance symptoms. Plant Physiol. 157:1528-1536. 